\title{
A Study on Products and Services of Apple Inc.
}

\author{
Tilak Naik G. ${ }^{1}$ \& Vaikunth Pai T. ${ }^{2}$ \\ ${ }^{1}$ Student of MCA, College of Computer \& Information Science, Srinivas University, \\ Mangalore-575001, INDIA \\ ${ }^{2}$ College of Computer \& Information Science, Srinivas University, Mangalore-575001, India \\ E-mail: tilaknaik2696@gmail.com
}

Type of the Paper: Research Case Study.

Type of Review: Peer Reviewed.

Indexed In: OpenAIRE.

DOI: https://doi.org/10.5281/zenodo.1491388.

Google Scholar Citation: IJCSBE

\section{How to Cite this Paper:}

Tilak Naik, G. \& Vaikunth Pai T. (2018). A Study on Products and Services of Apple Inc. International Journal of Case Studies in Business, IT and Education (IJCSBE), 2(2), 67-76. DOI: https://doi.org/10.5281/zenodo.1491388.

International Journal of Case Studies in Business, IT and Education (IJCSBE)

A Refereed International Journal of Srinivas University, India.

(C) With Authors.

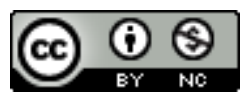

This work is licensed under a Creative Commons Attribution-Non Commercial 4.0 International License subject to proper citation to the publication source of the work.

Disclaimer: The scholarly papers as reviewed and published by the Srinivas Publications (S.P.), India are the views and opinions of their respective authors and are not the views or opinions of the S.P. The S.P. disclaims of any harm or loss caused due to the published content to any party. 


\title{
A Study on Products and Services of Apple Inc.
}

\author{
Tilak Naik G. ${ }^{1}$ \& Vaikunth Pai T. ${ }^{2}$ \\ ${ }^{1}$ Student of MCA, College of Computer \& Information Science, Srinivas University, \\ Mangalore-575001, INDIA \\ ${ }^{2}$ College of Computer \& Information Science, Srinivas University, Mangalore-575001, India \\ E-mail: tilaknaik2696@gmail.com
}

\begin{abstract}
Over the last 30 years, Apple has taken growth hence computer device design to developing customer electronics. Steve Jobs, Steve Woznaik, and Ronald Wayne founded the Apple Inc. in 1970's. Tim Cook is the current CEO of the company. Apple uses many types of internet business patterns. Business to Business E-Commerce used in the marketing of electronic inventions to help operate daily proficiency in other business. Business to Consumer ECommerce is the marketing of iPods, Computer, and other productions to vary individuals rather than Business. Apple's product line has developed rapidly in last few years. They are selling the products in the following categories: input device, output device, storage device, computers, and connecting devices. Apple is known to use a network called Airport Extreme Card picks up a Wi-Fi signal rather than a broadcast network. Apple is related Bonjor Connection. It is an automatic connection where computers and devices automatically transmit their own services and listen for services offered for the uses for the others. AirPort utility for Mac guides you through the process of connecting to the internet, and you will have your network up and running in minutes. Apple provides the four fundamental of network security by offering a valid source of confidentiality with their terms and agreement statement. Apple has their terms and agreement, which explains their integrity and availability. Whether looking up online or calling the store via phone any answer to any question answered honestly. Their security and access controls explain MAC OS X Server is built on an advanced architecture to deliver the features you want with the security you need.
\end{abstract}

Keywords: Apple Inc., Company Analysis, Internet Business Models, Airport Extreme Card, Bonjor Connection.

\section{INTRODUCTION :}

Company analysis is a crucial sort of case methodology in Research, which generally considered at the initial stage of scholarly research. Out of two ways of studying a company, the first way is on studying its business in terms of its products they develop and services that are offered. This additionally involves finding out numerous functions of the corporate that involves its productivity and sustainability. The second way is studying related to how the managers handle the critical situations and make strategic decisions to solve the company issues to realize its objectives. A systematic study and framework is developed for company analysis for reference [1-10]. Several systematic analysis frameworks are used in various company case studies to study and analyze internal aspects of working of company which includes ABCD analysis, SWOC analysis etc [11-19]. This paper discusses products and services of Apple Inc and its strategic methods to face competitions in similar products of other companies using various case study methodologies [20-26]. The internal and external opportunities are analyzed by means of SWOT analysis [17-19].

Apple Inc. is an American multinational fortune 500-technology based company headquartered in Cupertino, California. It focuses on designing, developing, and selling consumer electronic devices, software applications, and online services. The three of Steve Jobs, Steve Wozniak and Ronald Wayne were founded an Apple in April 1976, to design and sell Wozniak's Apple Ipersonal computer and integrated as Apple Computer, Inc. in January 1977, and sales of its computers, including the 
Apple II, saw significant momentum and revenue growth for the company. Within a short period, Jobs and Wozniak had hired a staff of computer architect designers and had a production unit. Apple went public in 1980 to instantaneous financial success. Over the next short period, Apple designed new computer featuring innovative graphical user interfaces, and received widespread critical applause. However, because of the high price tag of its IT products and limited software caused problems, as did power struggles between executives at the company. Jobs resigned from Apple and created his own company. As the increased demand for personal computers, Apple's computers saw diminishing sales due to lower-priced products from competitors, in particular those offered with the Microsoft Windows operating system. More executive job shuffles happened at Apple until then CEO Gil Amelio in 1997 decided to buy Jobs' company to bring him back. Jobs regained position as CEO, and began a process to rebuild Apple's status, which included opening Apple's own retail stores in 2001, making numerous acquisitions of software companies to build a portfolio of software titles, and has changed some of the hardware technology components used in its computers and found success and attained profitability. In January 2007, Jobs has announced that Apple Computer, Inc. would be renamed Apple Inc. to reflect its shifted focus towards consumer electronics devices and introduced the iPhone, which saw critical acclamation and significant financial success.

\section{OBJECTIVES :}

* To study and understand the type of products and services provided by the company.

* To analyze the overall growth of the company.

* To find the different initiative that will help in environmental sustainability.

* To understand the HR training strategies and corporate social responsibilities of the company.

* To find the competitors of Apple Inc.

\section{ABOUT APPLE INC :}

Apple is the world's biggest IT Company by income \& the world's third biggest mobile phone producer. In Feb 2015, Apple became the first U.S. based company to be precious at over US $\$ 700$ billion. Apple's global annual income totalled \$229 billion in the financial year of 2017. From January 2016, above 1 billion products of Apple are actively in use in the world. 23,000 fulltime employees as of September 2017 \& manages 500 retail shops in 22 different countries as of December 2017. Apple efficiently manages the iTunes Store, which is the world's leading music merchandiser. The company enjoys its high level of brand and has continuously ranked as the world's most valuable and acceptable brand. However, it receives significant criticism about the labour practices of its contractors with its ecological and business practices, including the origins of source materials.

\section{SMART PRODUCTS AND SERVICES :}

\subsection{Mac:}

- iMac: Introduced in 1998 and it is an all-in-one consumer desktop computer.

- Mac Mini: Introduced in 2005 and it is a consumer sub-desktop computer.

- MacBook: Introduced in 2006 and launched in 2015 and it is a Consumer ultra-thin, ultraportable notebook.

- MacBook Pro: Introduced in 2006, and it is a Professional notebook.

- Mac Pro: Workstation desktop computer, introduced in 2006.

- MacBook Air: Introduced in 2008, Consumer ultra-thin, ultra-portable notebook.

4.2 iPod: In the year of 2003 October 23, Apple introduced digital music player called iPod. Varieties of updated models have since been introduced, and the iPod brand is now the market leader in portable music players by a significant margin.

4.3 iPhone: Steve Jobs introduced much-anticipated iPhone in January 2007, a convergence of an Internet-enabled smartphone and iPod.

4.4 iPad: On January 27, 2010, Apple introduced media tablet called the iPad. It offers multi-touch interaction with multimedia formats including newspapers, e-books, photos, videos, music, word processing documents, video games, and most existing iPhone apps using a 9.7-inch screen. It also 
includes a mobile version of Safari for web browsing, as well as access to the App Store, iTunes Library, iBook store, Contacts, and Notes.

4.5 Apple Watch: Tim Cook declared the original Apple smart watch on September 9, 2014, introduced as a product with health and fitness tracking. It had been free on Gregorian calendar month twenty-four, 2015. The ordinal generation of Apple Watch, Apple Watch Series a pair of, was free in September 2016 that includes bigger waterproof, a flash processor, and brighter show. On September 12, 2017, Apple introduced Apple Watch Series 3 that includes LTE cellular property, giving the wearable independence from AN iPhone aside from the setup method.

4.6 Apple TV: Jobs incontestable the Apple TV at the 2007 Macworld conference, a set-top video device planned to bond the sale of content from iTunes with high-definition TV. The device links up to a user's TV and syncs, via either Wi-Fi or a wired network, with one computer's iTunes library and streams content from an extra four. The Apple TV originally engineered with a forty GB Winchester drive for storage, enclosed outputs for HDMI and part video with high resolution video quality of 720p.

4.7 Software: Apple introduced its own operating systems to run on its devices, conjointly for macOS for mackintosh personal computers, iOS for iPhone, iPad and iPod bit smartphones and tablets, watchOS for its Apple Watch smart watches, and tvOS for its Apple TV digital media player.

For iOS and macOS, Apple develops its own software system titles, as well as Pages for writing, Numbers for spread sheets, and Key note for shows, as a part of its iWork productivity suite. For macOS, it conjointly offers iMovie and movie professional X for video writing, and Garage Band and Logic Professional X for music creation.

Apple conjointly offers on-line services with iCloud, that provides cloud storage and synchronization for a large vary of user knowledge, as well as documents, photos, music, device backups, and application knowledge, and Apple Music, its music and video streaming service.

4.8 Electric vehicles: According to the Sydney Morning Herald, Apple needs to start out manufacturing an electrical automobile with autonomous driving as shortly as 2020. Apple has created efforts to recruit battery development engineers and alternative electric car engineers from A123 Systems, LG Chem, and Samsung physics, Panasonic, Toshiba, Johnson Controls and Tesla Motors.

4.9 Apple Energy: Apple Energy, LLC may be an all owned subsidiary of Apple opposition. That sells solar power. As of Gregorian calendar month vi, 2016, Apple's star farms in American state and American state are declared to supply 217.9 megawatts of star generation capability. Additionally, to the company's solar power production, Apple has received regulative approval to construct a lowland gas energy plant in North Carolina. Apple can use the gas emissions to get electricity. Apple's North Carolina knowledge centre is already powered entirely with energy from renewable sources.

\section{CUSTOMERS AND STAKEHOLDERS :}

Apple considers the interests and considerations of variety of key stakeholders in its policies and programs for company social responsibility. Neutral teams impose variable demands in several aspects of business. In Apple's case, the subsequent stakeholders are the foremost significant:

Customers/Consumers: Apple prioritizes purchasers as its prime stakeholders in devising corporate social responsibility strategies. This neutral cluster is confident of individual and structure patrons of Apple merchandise. The most interest of consumers is to possess effective and economical merchandise that are inexpensive. Apple merchandise has higher value points. However, Apple's premium rating arrange is appropriate as a result of it matches the top quality and principles art of those merchandise. The corporate conjointly has environmental programs for usage and accountable sourcing to handle customers' demands for business endurable. Thus, Apple's company social responsibility intention satisfies the interests of consumers because the prime stakeholders of the business.

Apple's workers: Workers are the second-priority stakeholders in Apple's approach to company social responsibility. This neutral cluster consists of workers at Apple's facilities. The most interests of those stakeholders are correct compensation and career development. Workers as a neutral cluster are necessary as a result of they directly verify Apple's human resource capabilities to introduce and develop profitable merchandise. The firm addresses the interests of its workers through compensation 
packages competitive in Silicon Valley. Thus, Apple's company social responsibility efforts satisfy the considerations and interests of workers as a serious neutral cluster.

Investors: Investors are generally major stakeholders and determinants of company social responsibility activities in business. In Apple's case, investors have an interest in increasing the returns on their investments. The corporate effectively addresses this neutral cluster through wonderful money performance. For instance, Apple is currently one in every of the foremost profitable corporations within the world. The firm has maintained high profit margins. Apple additionally incorporates a robust money position that involves high liquidity through massive amounts of money. The corporate has additionally managed to avoid debt and supported these company social responsibility conditions. Apple effectively satisfies the interests of investors as stakeholders.

Employees of Suppliers and Distributors: Staff in Apple's also important issues within the company's company social responsibility efforts. These Staff are indirect stakeholders in Apple's business; however verify the firm's company social responsibilities. The most interest of this neutral cluster is analogous to the interests of Apple's own workers; admire correct compensation and job security. In addition, this neutral cluster is fascinated by moral employment practices. To deal with these interests, Apple incorporates a provider Code of Conduct. The corporate monitors and imposes needs on the use practices of corporations in it's provide chain. A part of Apple's policy is to terminate business relations with suppliers that still fail or refuse to satisfy this Code of Conduct. Apple's 2014 assessment of suppliers shows that ninety-two of suppliers currently befit the 60-hour work time rule. Thus, to a precise high degree, Apple's company social responsibility efforts satisfy the interests of the neutral cluster of suppliers' staff.

\section{HR TRAINING AND STRATEGY :}

A success of a corporation is not solely a result of unbelievable producing capability and nice location. Many times, HR strategy becomes the explanation for company to square robust and grows massive to rule the planet. Apple is one example of such company. Nice skills and strange talent management approaches are thought-about because the most significant reasons why Apple may be the leader in shopper physics. Actually, Apple does not open up with company's 60-minute's strategy. It is not arduous to grasp why company tries to cover their secret, because of competition is fierce. However, some folks were tried arduous to analyse 60 minute's strategy at Apple. They interviewed 60 minute's leaders and talked with former staff to search out it out. Recruiting are some things that become they key of success. Apple needs all candidates to be striving, committed to the corporate, and find each precise detail excellent. Many times, Apple recruits high-quality staff from alternative corporations. Some folk's decision it pirate predatory. Apple understood as a unique company in many ways. Rather than promising work and life balance, Apple is action diligence for all staff. Rather than promising career progression, Apple conception is for workers to have their career. career path is not absolutely supported by Apple. Workers should obtain data concerning alternative jobs in numerous units themselves. Apple makes things thus very different in talent management. Rather than providing coaching and development program, Apple creates the staff sleep with them. Trainings offered however, Apple does not provide or produce learning set up for the staff. Apple reinforces the staff to own robust independent and develop their skills on their own. However, the strategy appears work well for each company and staff. From the terribly starting, staffs apprehend that they might not expect heat family within the corporate. They apprehend that they need to become one thing special to survive. Therefore, while not coaching and development program, staff already learns, train, and develop them. Yet, they are doing not regret it because of the apprehend that they are going to receive superb come back if they might provide one thing unbelievable for the corporate. New challenge when a project is another key purpose of attraction. It might create folks have new spirit and sure enough will not expertise boring. Workers are continuously pro-active and inquisitive about what is going to happen tomorrow. They continuously prepare themselves to be told one thing new that produces life thus exciting. With such strategy, Apple must not supply coaching and learning program because of the staff can obtain it themselves. Apple must not produce development program as a result of the staff can develop themselves. This is how Apple trains their workers to be inventive and innovative. 


\section{FINANCIALS :}

Apple designs, manufactures, and markets personal computers, portable digital music players and mobile communication devices. It also markets a range of related software, services, peripherals and networking solutions. The company offers its products and services to customers in education, consumer, creative, professional, business and government sectors. In addition, it sells various thirdparty Macintosh (Mac), iPod, iPad and iPhone compatible products that include application software, printers, storage devices, speakers, headphones, and various other accessories and peripherals. Apple offers a range of personal computing products, which include desktop and portable personal computers, related devices and peripherals, and various third-party hardware and software products. Additionally, it designs, develops and markets, its family of iPod digital music players and its iPhone mobile communication devices, along with related accessories and services such as the online distribution of third-party content through the company's iTunes Store.

On November 2, 2017, Apple announced financial results for its fiscal 2017 fourth quarter ended September 30, 2017. The Company posted quarterly revenue of $\$ 52.6$ billion, an increase of $12 \%$ from the year-ago quarter, and quarterly earnings per diluted share of $\$ 2.07$, up $24 \%$. International sales accounted for $62 \%$ of the quarter's revenue.

Apple is providing the following guidance for its fiscal 2018 first quarter:

- revenue between $\$ 84$ billion and $\$ 87$ billion

- gross margin between 38 percent and 38.5 percent

- operating expenses between $\$ 7.65$ billion and $\$ 7.75$ billion

- other income/(expense) of $\$ 600$ million

- tax rate of 25.5 percent

Apple's board of directors has declared a cash dividend of \$0.63 per share of the Company's common stock. The dividend is payable on November 16, 2017 to shareholders of record as of the close of business on November 13, 2017.

\section{CORPORATE SOCIAL RESPONSIBILITY :}

Apple company social responsibility (CSR) programs and initiatives are light-emitting diode by Lisa Jackson, vice chairperson of Environmental Initiatives, news on to chief executive officer Tim Cook. It has to be noted, "Steve Jobs wasn't legendary for financial aid. Some questioned if he created anonymous donations to charity, some criticized him for his lack of public giving, whereas others defended him. However, with Tim Cook forward Apple leadership in 2011, the main target on CSR facet of the business was doubled to a substantial extent. Tim Cook may be a member of Paulson Institute's chief executive officer Council for property Urbanization, operating with different CEOs of high Chinese and Western corporations to advance property in China.

- Apple CSR Programs and Initiatives includes

- Apple Supporting Local Communities

- Apple Educating and Empowering Workers

- Labour and Human Rights at Apple

- Employee Health and Safety at Apple

- Apple and Gender Equality and Minorities

- Energy Consumption by Apple

- Water Consumption by Apple

- Waste Reduction and Recycling by Apple

- Carbon Emissions by Apple

- Apple and Sustainable Sourcing

- Charitable Donations by Apple

\section{ANALYSIS :}

\section{Company Background}

Name

Apple Inc. 


\begin{tabular}{|c|c|}
\hline Logo & \\
\hline $\begin{array}{l}\text { Industries } \\
\text { served }\end{array}$ & $\begin{array}{l}\text { Computer hardware (Mac, iMac, Mac Pro, MacBook, MacBook Air) } \\
\text { Computer software (iOS, OS X, Safari, life, iWork, iMovie, iPhoto) } \\
\text { Consumer electronics (iPod, iPhone, iPad, Apple TV and Mac products) } \\
\text { Digital distribution (iTunes store, iCloud, App Store, Mac App Store) }\end{array}$ \\
\hline $\begin{array}{l}\text { Geographic } \\
\text { areas served }\end{array}$ & Worldwide (retail stores in 22 countries and online stores in 100 countries) \\
\hline Headquarters & Cupertino, California, United States \\
\hline Current CEO & Tim Cook \\
\hline $\begin{array}{l}\text { Revenue } \\
\text { (US\$) }\end{array}$ & 229.234 billion (2017) 6.3\% increase over 215.639 billion (2016) \\
\hline Profit (US\$) & 48.351 billion (2017) 5.8\% increase over 45.687 billion (2016) \\
\hline Employees & $123,000(2017)$ \\
\hline $\begin{array}{l}\text { Main } \\
\text { Competitors }\end{array}$ & $\begin{array}{l}\text { Samsung Electronics Co., Ltd., Amazon.com, Inc., International Business } \\
\text { Machines Corporation, Cisco Systems, Inc., Google Inc., Microsoft } \\
\text { Corporation, Dell Inc., LG Electronics, Lenovo Group Limited, Hewlett- } \\
\text { Packard Company, Sony Corporation and many other computer hardware, } \\
\text { computer software, consumer electronics and Internet companies. }\end{array}$ \\
\hline
\end{tabular}

\section{Strengths:}

1. Unique ability to design and develop proprietary hardware, software, applications and services

2. Powerful brand supported by strong advertising and marketing capabilities

3. Strong brand image

4. Vertical integration

5. Brand awareness and reputation

6. Sound financial performance with one of the strongest cash flows

7. Effective rapid innovation processes

\section{Weaknesses}

1. Overdependence on iPhone sales

2. Weak direct distribution channels in India

3. Limited distribution network

4. High selling prices

5. Dependence of sales based on high end market segments

6. Low expenditure on research and development compared to other companies leads to fewer innovations and products introduced to the market

7. Incompatibility with other OS

\section{Opportunities:}

1. The Internet of Things (Iota) market is expected to grow significantly over the next decade 
2. Health-related wearable gadgets could be introduced to the market

3. Expanding mobile payments market

4. The mobile enterprise app market will gain traction as more businesses shift toward buying subscription-based software

5. Expansion of the distribution network

6. Higher sales volumes based on rising demand

Threats:

7. Development of new product lines

1. Intensifying competition puts pressure on Apple's market share, revenue and profits.

2. Strong U.S. dollar

3. Lawsuits over patent infringements resulting in damaged brand reputation

4. Risk of data breaches

5. Aggressive competition

6. Imitation

7. Rising labour cost in various countries

\section{COMPETITORS :}

- Dell competes with Apple in the market of consumer PCs. Competition between Dell and Apple began when the former launched a rival product Dell DJ that although brought in significant revenue, it still didn't match the standards and success of Apples iPod. With a few years have passed on, these two companies even compete fiercely with Dell's XPS line taking Apple head-on in the PC market.

- Lenovo is one of the Apple Competitors for all its products - Smartphones, Laptops and Tablets. Lenovo has an excellent range of laptops and has an in depth product portfolio. Although it lacks in Marketing and Brand equity.

- When compared to Apple, Samsung can be the primary competitor to Apple's Smartphones The Iphone. Samsung's Galaxy series and Note series are both premium series which are the major reason for dents in Iphone sales. Although Samsung is the go to brand for Smartphones, the same cannot be said about its laptop. Samsung does not have an equivalent high brand equity for its laptop segment but due to the residual branding of Smartphone, there is greater awareness and adoption of Samsung Laptops. When we consider Samsung as one of the top Apple competitors, we are definitely considering its smartphone as a competitor much above their laptops.

- HP Inc., has made tremendous strides as it continues to provide users with quality and affordable products and is. Today with over 300, 000 employees worldwide, HP Inc. competes with top brand Apple. Hewlett packard also has a wide consultancy presence across the globe and is not concentrated on the US. As a result, Hewlett packard is a strong Macbook competitor and competitor for all Apple laptops.

- Microsoft and Apple have made huge stride through their years. There is stiff competition between these two brands, especially for the computer, smartphone, and entertainment media markets.

- Asus is a lower end competitor to Apple and one of the reasons Apple needs to keep an Eye on Asus is because of its small netbooks. Macbook Air is one of the most loved Apple laptops because of small size and weight and battery capacity. Asus has several models which fall close and hence it is considered as one of the Apple Competitors.

\section{SUGGESTION :}

Based on the strategic issues highlighted in this SWOT analysis of Apple Inc., a recommendation is to continue the aggressive and rapid innovation involved in developing the company's products. Such innovation reduces the adverse effects of imitation on revenues. Also, it is recommended that the company further enhance the automation of its production processes, and support the automation of its contract manufacturers, as a way of addressing the rising labour costs involving Apple product manufacturers. Another recommendation is to establish partnerships with more distributors to improve the overall market reach of the company's distribution network. 


\section{CONCLUSION :}

The various internal and external factors mentioned and discussed in SWOT analysis shows that Apple Inc. has major positive strengths to effectively address various organizational weaknesses. The corporate may also encash these strengths to take advantage of its opportunities, like the enlargement of its distribution network. Moreover, the company can encash its strong product brand image and rapid innovation processes to design, develop and come up with new innovative products. However, Apple faces the serious threats of aggressive competition and imitation from other companies that are working on similar technologies, which are major significant challenges affecting the players in the global market for consumer electronic devices, computer hardware components and software applications, and online digital content distribution channels.

\section{REFERENCES :}

[1] Aithal, P. S. (2017). Industry Analysis - The First Step in Business Management Scholarly Research. International Journal of Case Studies in Business, IT and Education (IJCSBE), 2(1), 113. DOI: http://dx.doi.org/10.5281/zenodo.810347.

[2] Aithal, P. S., (2017). Company Analysis - The Beginning Step for Scholarly Research. International Journal of Case Studies in Business, IT and Education (IJCSBE), 1(1), 1-18. DOI: http://dx.doi.org/10.5281/zenodo.573769.

[3] Jithin Raj, K. \& Krishna Prasad, K. (2018). A Critical Study on Business Strategies of 3i Infotech Ltd. International Journal of Case Studies in Business, IT and Education (IJCSBE), 2(1), 13-21. DOI: http://dx.doi.org/10.5281/zenodo. 1247319.

[4] Aithal, P. S. (2017). An Effective Method of Developing Business Case Studies based on Company Analysis. International Journal of Engineering Research and Modern Education (IJERME), 2(1), 16-27. DOI: http://dx.doi.org/10.5281/ZENODO.400579.

[5] Aithal Architha \& Aithal P. S. (2018). How and Why Wharton Business School became World Topper - A Case Study on Organizational Quest for Excellence of First US Business School. International Journal of Application or Innovation in Engineering \& Management (IJAIEM), 7(1), 15-42. ISSN 2319 - 4847, DOI : http://doi.org/10.5281/zenodo.1164718.

[6] Keerthan R. \& Aithal, P. S. (2018). A 'Desi' Multinational - A Case Study of Hindustan Unilever Limited. International Journal of Case Studies in Business, IT and Education (IJCSBE), 2(1), 112. DOI: http://dx.doi.org/10.5281/zenodo.1147365.

[7] Aithal P. S., Anil Kumar, Madhushree, \& Revathi R. (2018). Investigation of Business Strategies in Higher Education Service Model of Selected Private Universities in India. International Journal of Computational Research and Development (IJCRD), 3(1), 77-100. DOI : http://doi.org/10.5281/zenodo.1209910.

[8] Madhushree, Revathi R. Anil Kumar, \& Aithal, P. S. (May 2018). Business Strategy of Top Indian IT Company: MindTree. International Journal of Case Studies in Business, IT, and Education (IJCSBE), 2(1), 22-36. DOI: http://dx.doi.org/10.5281/zenodo.1249871.

[9] Aithal, P. S. (2017). Factor Analysis based on ABCD Framework on Recently Announced New Research Indices, International Journal of Management, Technology, and Social Sciences (IJMTS), 1(1), 82-94. DOI: http://dx.doi.org/10.5281/zenodo.584105.

[10] Aithal, P. S., (2017). ABCD Analysis as Research Methodology in Company Case Studies. International Journal of Management, Technology, and Social Sciences (IJMTS), 2(2), 40-54. DOI: http://dx.doi.org/10.5281/zenodo.891621.

[11] Aithal, P. S. \& Suresh Kumar, P. M. (2016). Innovations in Private Universities : A Case of Srinivas University. International Journal of Management, IT and Engineering (IJMIE), 6(1), 250-264. DOI : http://doi.org/10.5281/zenodo.161151. 
[12] Aithal, P. S. \& Suresh Kumar, P. M. (2017). Challenges and Opportunities for Research \& Publications in Higher Education. International Journal of Scientific Research and Modern Education (IJSRME), 2(1), 42-49. DOI: http://dx.doi.org/10.5281/Z ENODO.400619.

[13] Paul P. K., Aithal, P. S., Bhuimali A., \& Krishna Raj, (2017). National Telecommunication and Information Administration (NTIA): The Promoter of Digital Humanities and Sociology- $A$ Case Study, International Journal of Scientific Research in Physics and Applied Sciences, 5(4), 24-27. DOI: http://doi.org/10.5281/zenodo.888201.

[14] Sridhar Acharya, Aithal, P. S., (2017). Opportunities and Challenges of Producing Solar Energy in Every Indian Home - A case Study. International Journal of Case Studies in Business, IT and Education (IJCSBE), 1(2), 114-119. DOI: http://dx.doi.org/10.5281/zenodo.1133921.

[15] Aithal, P. S., (2016). Study on ABCD Analysis Technique for Business Models, business strategies, Operating Concepts \& Business Systems, International Journal in Management and Social Science, 4(1), 98-115. DOI : http://doi.org/10.5281/zenodo.161137.

[16] Aithal, P. S., Shailashree, V. T., Suresh Kumar, P. M. (2015). A New ABCD Technique to Analyze Business Models \& Concepts. International Journal of Management, IT and Engineering (IJMIE), 5(4), 409 - 423.DOI : http://doi.org/10.5281/zenodo.61652.

[17] Aithal, P. S. Suresh Kumar, P. M. (2015). Applying SWOC Analysis to an Institution of Higher Education. International Journal of Management, IT and Engineering (IJMIE), 5(7), 231-247. DOI : http://doi.org/10.5281/zenodo.163425.

[18] Laveena D’Mello. (2017). NGO’s Intervention to Bring Change in the Society- A Case Study of 'SIRRA'. International Journal of Case Studies in Business, IT and Education (IJCSBE), 1(1), 19-26. DOI: http://dx.doi.org/10.5281/zenodo.580084.

[19] Sneha, M. S. \& Krishna Prasad, K. (2018). Analysis of Business Strategies of Salesforce.com Inc. International Journal of Case Studies in Business, IT and Education (IJCSBE), 2(1), 37-44. DOI: http://dx.doi.org/10.5281/zenodo.1252028.

[20] Yin, R. K. (1992). The case study method as a tool for doing evaluation. Current Sociology, 40(1), 121-137.

[21] Stake, R. E. (1978). The Case Study Method in Social Inquiry. Educational Researcher, 7(2), 5-8.

[22] Flyvbjerg, B. (2006). Five misunderstandings about case-study research. Qualitative Inquiry, 12(2), 219-245.

[23] Gerring, J. (2004). What is a case study and what is it good for?. American Political Science Review, 98(2), 341-354.

[24] Runeson, P. \& Höst, M. (2009). Guidelines for conducting and reporting case study research in software engineering. Empirical Software Engineering, 14(2), 131.

[25] Bowen, G. A. (2009). Document analysis as a qualitative research method. Qualitative Research Jjournal, 9(2), 27-40.

[26] Noor, K. B. M. (2008). Case study: A strategic research methodology. American Journal of Applied Sciences, 5(11), 1602-1604.

[27] Apple Inc. (2018, May 23). Retrieved from https://en.wikipedia.org/wiki/Apple_Inc.

[28] Training | Apple Inc. (n.d.). Retrieved from https://training.apple.com

[29] Corporate Social Responsibility Policy | Apple Inc. (n.d.). Retrieved from https://www.apple.com/in/legal/policies/Apple_India_2015_CSR.pdf

[30] Business | Apple Inc. (n.d.). Retrieved from https://www.apple.com/lae/business 